\section{Maori Education in 1993: A Review and Discussion}

\author{
KATHIE IRWIN
}

\author{
Tungia te ururua \\ Kia tupu whakaritorito \\ te tapu o te harakeke. \\ Clear away the undergrowth \\ so that new shoots (ideas) \\ may emerge. \\ (Henare et al., 1991, p. 47)
}

W

as 1993 a happening year or was 1993 a happening year! A number of significant events, in national as well as global terms, occurred. It was: the centenary year of Women's Suffrage in Aotearoa; the International Year of the World's Indigenous People, linking "an estimated 250 million indigenous people in more than seventy countries around the world" (Te Puni Kokiri, 1993a); an election year; and the final year of the Development Decade, which was outlined as the third objective of the kawenata, the covenant, declared by Maoridom at the Hui Taumata, the Maori Economic Development Summit held in 1984, marked in Te Rapa this year with the holding of the 1993 National Commercial and Economic Development Conference, organised by the Ki Tua o Te Arai Trust (Te Puni Kokiri, 1993b). Each of these events has major implications for Maori education during 1993 and beyond. Analyses of the implications of these events for Maori education provide the major organising themes for this paper. The events of 1993 have stimulated much critical debate, research and scholarly analyses of the issues they encompass. We will all be the richer for the publication of these new works. Numerous conferences have been held and books launched. Some of the books capturing this year's themes with significance for Maori education include: Standing in the Sunshine (Coney, 1993); Maori Women and the Vote (Rei, 1993); Nga Mahi Whakaari a Titokowaru, Ruka Broughton's previously unpublished draft doctoral thesis (Broughton, 1993) (the first Maori text on Titokowaru to be published, following the two previously published texts in English by Pakeha writers); Learning Liberation: Women as Facilitators of Learning (Manchester and O'Rourke, 1993); Te Ara Tika: Maori and Libraries - A Research Report (MacDonald, 1993); Educating Feminists: Life Histories and Pedagogy (Middleton, 1993); Te Maori i roto i nga Mahi Whakaakoranga - Maori in Education (Davies and Nicholl, 1993); Women Together: A History of Women's Organisations in New Zealand (Else et al., 1993); and Te Hikoi Marama, Volume 2 - A Directory of Maori Information Resources (Szekely, 1993).

An important outcome of this year is the tremendous opportunities for community and continuing education that have occurred. Beyond the classroom walls there has been a plethora of educational opportunities created and enjoyed by many at hui, conferences, seminars, lunchtime and evening speeches and debates. So visible were some of these learning forums this year that some people claim to have been saturated by them, others to be concerned about the money used to fund them. Interestingly, whilst Women's Suffrage Year and the Election and MMP/FPP campaigns fall into this category, the Year of Indigenous Peoples seems to have escaped such comment. Indeed, on reflection, the Year of Indigenous Peoples seems to have excited indigenous people more than anyone else and has certainly not been publicly identified as costing an awful lot to hold. I wonder why?

Then there was what seems to me to be one of the seedier aspects of Maori educational happenings in 1993, a perennial issue we face, which I will only comment briefly on. Anyone, it seems, who had anything negative to say or report about Maori education, still found a forum to do so in 1993.1 have yet to see a 
syndicated column on positive or effective areas of Maori education outside of the Maori media, in any of the other papers or magazines that I have read throughout the country this year. This is not a time to let the public at large be bombarded by a relentless diet of negative reporting! Particularly not when an increasing number of publications and detailed research reports on Maori education offer an informed, scholarly, well researched alternative in which the discourse is critical, not totally and predictably negative. And there is a significant difference in this. This is not to say that there are not major areas of Maori education which we need to continue to be concerned about: there are. And issues that still need to be critically and fearlessly examined: again, there are. But critical analysis means making a reasoned, well researched case built on facts and presented using a logically developed argument. It also means publishing this material so that a wide readership can access the work and judge for themselves the contribution it makes.

That news is only news if it is bad news may be something of a truism to media watchers. However, in this context it is a warning to all educationists to be very very wary of the image of Maori education the public at large gleans from the mainstream print media and to go on the offensive. The "news" about Maori Education is far too important to leave to this area of the media to shape and disseminate alone. The offensive we need to be part of is one of a major exercise in public relations: ensuring that the vitality and complexity of the field that is Maori education is accurately and continuously communicated to the public at large. The growth in the publication of Maori sources of print media is testimony to the availability of alternative sources of "news" about happenings in the Maori community, including what is happening in Maori education. 1993 saw the addition of an important new source of such material through the launch of Mana Magazine, a bimonthly high quality glossy Maori magazine. Each issue this year has contained significant sections on Maori education. There is a "market" for informed, wider and critical reporting of Maori education and Maori issues. Mana and the numerous Maori newspapers that are now available are capturing this opportunity to take a view of what is news and what is current affairs to the people directly and this includes "news" about education.

\section{Election Year and Other Matters Relating to the Government and its Agencies}

It was also an election year. And, as is the case now in election year, since Roger Douglas first made public the Treasury Briefing Papers to the Incoming Government in 1984 (Coddington, 1993, p. 10), public servants have been busy preparing "pebs" for the incoming government which are available to the public. "Pebs" are the post election briefing papers prepared by each government department or Ministry for the incoming Minister providing an up-to-date account and analysis of their work. They provide valuable sources of information for those wishing to be informed with the latest knowledge about the work of the government. Academics and educational researchers are able to access these "pebs" and to use them in their research. Indeed, any individual can use them, providing they know that such pebs exist, that they are available by requesting them using the Official Information Act if necessary, who to contact to make the request, what to ask for, and where to find each of the many agencies now involved in different aspects of education. Though available, whether this information reaches the flaxroots people in the community, now heavily involved in educational management and governance through the work of Boards of Trustees, is a moot point. As a response to this NZCER and He Parekereke, VUW, are currently negotiating with the ministries and government departments whose work impacts on Maori education to publish an edited collection of these "pebs" early in the New Year, so that they can be readily accessible to communities and schools to assist in their work. The publication will aim to bring together a complete set of such papers from all of the agencies with responsibilities in the area of Maori education. The compilation of the set, their coordination into an edited collection and an editing 
process which will be undertaken to ensure that the language used is accessible to a wide and general readership will ensure this resource reaches the widest readership possible.

A number of significant education reports and education policy documents have been released by the Ministry of Education this year providing a major source of definitive data of the kind critical for effective policy making. Those of particular significance for this review are: Maori in Education (Davies and Nicholl, 1993), The Status of Girls and Women in New Zealand Education and Training (Sturrock, 1993), and Three Years On: The New Zealand Education Reforms 1989 to 1992 (Ministry of Education, 1993a). The publication of these reports at a time when planning for education into the twenty-first century is underway is crucial. Such planning must be informed by the kind of comprehensive and accurate educational, social and economic data bases that these reports provide. Without the publication of such reports the community with an interest in education can only be poorly placed to offer informed comment on them. Education for the 21st Century (Ministry of Education, 1993b), New Zealand Curriculum Framework (Ministry of Education, 1993c), Te Whariki (Ministry of Education, 1993d) and the Ten Point Plan (Ministry of Education, 1993e) were all released in 1993.

Whilst we were all invited to obtain copies of these publications (a number were issued free to all schools), to read them and to make submissions about them, this was a difficult exercise without the other reports which provided the requisite statistics and analysis, as well as reviews of relevant research and literature, from which to base sound judgement and informed analysis. Read together the task of commenting on educational policy and curriculum development, of the kind sought, was a manageable and fruitful exercise. Without the background reports, however, it was an exercise of crystal ball gazing, of the kind education can well do without. Such reports need to be released regularly to enable this critically important educational data to be routinely updated so that close analysis and monitoring of trends can occur throughout the educational community.
And the emphases, in italics, are deliberate. We have seen annual educational statistics published in the past but the discussion and analysis sections were cursory, making them documents which were almost illegible to the public, beyond the trained statistician. Certainly not "user friendly" to the untrained, non-mathematician, which many of us are. Take the 1989 edition of Education Statistics of New Zealand (Ministry of Education, 1990), for example. It is 153 pages long, with tables 1-95 listed from pages 15-153. No text or discussion or analysis or pictures in those 138 pages of endless tables and figures. Eight pages of text at the beginning of the document describe the ISCED levels used (International Standard Classification of Education); two summarise the trends in education 1978-1988. That may have been okay in the pre-Picot days of education. But, in post-Picot education it is not okay. Given the role that the wider community now plays in educational management and governance, as a result of the post-Picot reforms, at the very least it seems reasonable to expect that government, through its various ministries, will regularly provide people with the knowledge that they need to do their jobs in education effectively, and in an accessible manner.

Failure to publish such materials, on an annual basis, from the range of government ministries and agencies who now all work in education, will result in this valuable knowledge being available to the government only, through its own public servants. That will place the government in the best position to offer advice to itself on its own policies, policy directions and accomplishments, from its own staff, now intensely drilled in the new post restructuring language: "the Minister is our client, the Minister is the person who buys our output categories, the Minister is the person to whom we are directly accountable, the Minister is the only person who we answer to", or words vaguely like those. That, it seems to me, is a little self serving on the government's part. Just a fraction narcissistic. There is a need for all these new post-Picot educational agencies to make available, on an annual basis, user friendly summary versions of what they 
do and what they know. Upgraded user friendly versions, if you like, of their annual reports, copies of which are bound in the AJHR (Appendices to the Journals of the House of Representatives), the researchers' lifeline, which could go out to the flax and grassroots people, as a matter of course. This may be read as a naive suggestion from the dreaded, never costed, wish list of educational change idealistic non-public servants are wont to refer to. That may be so ... but these same flax and grass roots people this year voted in MMP and sent a message to the Ministers of the Crown, and other MPs, whom the public service now serve as "clients", that they wanted a new style of government, a new way of operating. Importantly, that they want to be informed and consulted about the work of government. Empowering the public service to empower the people by modifying what they already prepare for the Minister and Parliament anyway, does not, actually, seem like such a naive suggestion if increased community knowledge about the work and workings of the public service becomes classed as a regular category of Ministerial output. It could even be considered as a strategy which might endear Ministers and their public servants to their voting public ... now there's a frightening post-MMP thought! The need for widespread dissemination of such information is considerable in the community as a whole. This is particularly so for the Maori community. Knowledge is power. At this juncture in our history increasing demands are being placed on Maori people to be involved in self initiated programmes of development. To be effective in the long term, such work needs to be supported by the most comprehensive data bases available. The government has this knowledge to inform its own work. It could easily make it more accessible to the community at large, particularly the Maori community for whom access to such knowledge is a vital and pressing concern.

In this regard the Ministry of Education is to be congratulated for the taking the lead in 1993 by providing the educational community with high quality, more user friendly resources to assist them to effectively undertake the tremendously important work that the community now undertakes in education. These include resources which are gender and Maori inclusive, which include specialist analyses on Maori women, and which include analyses across all sectors of the schooling system, including early childhood and the various parts of the tertiary sector; resources which are, in summary, comprehensive and therefore more useful.

\section{Women's Suffrage Year: the Personal is Political and Politic}

The two most reliable indicators of wealth, economic status, social role and political participation in New Zealand are still gender and race. The sex and race of a child are, together, likely to be the most significant predictors of that child's social and economic equality in adulthood. Their importance outweighs the overall impact of individual aptitude, intelligence, place of birth, place in family and age (Ministry of Education, 1990, pp. 9-10).

That the personal is political is no news to feminists, it is a basic tenet of feminist consciousness and action. The question of importance to me as a Maori feminist is: what is the nature of the political struggle we are engaged in. Just who constitutes the we is itself open to debate. In this context, for me, the "we" is a collective Maori reality and identity. If I am asked to speak from my personal experience, as a Maori feminist, it is framed by a collective reality. The reality is that we are engaged in a number of struggles, simultaneously. A critical, and for many Maori, most important struggle, is that framed by the Treaty of Waitangi, between Maori and Tauiwi.

Suffrage year has provided a time for reflection and analysis. How far have we come, as women, in Aotearoa from that time of fervent activism and change? What would we count as our successes? What issues have we resolved for all time? What ground made, never to be under contestation again? During this period of intense analysis as a Maori feminist, I have had to struggle with how I could look back at 100 years of political struggle for our women during this year of "celebrations" without 
misrepresenting the range of herstories during that time, many of which are deeply painful and oppressive; so experienced because they tell stories of Maori women who pursued what they believed were their basic civil and human rights, and who had the vision, courage and determination to make their dreams come true, against the odds, as Maori and as women.

The celebrations of women's suffrage marked this country as an international leader, a noteworthy point to make in these times of international positioning, as we are frequently enjoined to follow, rather than lead the world, in educational innovation. The lessons of the Suffragists on this, and other counts, remain exemplary. Not only did they exemplify "the personal is political" theme, a basic tenet of feminist consciousness and action, but also the rejoinder that "the personal is politic". They were brilliant tacticians and strategists (see Coney, 1993) knowing how, when and where to make effective contributions to the much needed social change, as keenly as they knew why they wanted this change to occur. Some women in the cause had the "right" connections and networks. Others had different connections and networks. All the networks and connections had to be sourced. They all struggled on, using whatever energy, insight, opportunity they could muster.

That women working in this cause were positioned differently by the signing of the Treaty of Waitangi, depending on whether they were Maori or Pakeha, has been a theme visited during this year of celebration. Patricia Johnson and Leonie Pihama (1993) addressed the theme of difference in an excellent, insightful paper presented at the annual NZARE Conference "What counts as difference and what differences count: gender, race and the politics of difference". Tania Rei (1993: 7) in Maori Women and The Vote has highlighted the dual causes and processes Maori women adopted during their Suffrage campaigns:
In the last decade of the nineteenth century, Maori women were involved in two suffrage movements at the same time. Maori women supported the Women's Christian Temperance Union (WCTU) in seeking the right to vote for members of the New Zealand House of Representatives, and they also sought the right to vote and to stand as Maori members of the Maori Parliament - Te Kotahitanga.

Taking part in the suffrage movement led by the WCTU was not without its cost: Maori women gave up the moko in order to belong. The following is the temperance pledge Maori women took if they joined the WCTU.

He whakaae tenei naku kia kaua ahau e kai tupeka, e mu ranei i tetahi mea e haurangi ai te tangata, kia kaua hoki ahau e whakaae ki te ta moko. Ma te Atua ahau e awhina.

I agree by this pledge, not to smoke tobacco, not to drink any beverages that are intoxicating, and also not to take the ta moko. May God help me. (White Ribbon, November 1989 as cited in Rei, 1993, p. 40).

The lesson we learn from this, as Maori, is that we are positioned to work on the dual kaupapa of major social reform for women and for Maori - at least dual, whilst our Pakeha sisters are not so positioned.

If ever there was a year to be a Maori feminist educator in Aotearoa New Zealand, this was it. I saw a lot of my well travelled mates at various airports for coffee as we flew in and out of Wellington, Auckland, Hamilton or wherever it was that we were taking part in this year of tremendous activity. Like a lot of other Maori, feminist and Maori feminist educators I spent the year travelling to and fro addressing groups about the issues on the agenda this year. The opportunities ranged. From very large and auspicious affairs, like the Great Feminist Debate in the Aotea Centre in Auckland, attended by over 500 women, to the lunchtime meeting in the Annex of the Otaki Town Hall in the company of some fifty or sixty women (Butterworth, 1993), to the evening meeting held in the small front meeting room of a 
Presbyterian Church in Gisborne, in the company of 20 or 25 women, women met and shared and talked and reflected on the lives and work and struggles and celebrations of the women of these lands. An affirmation of what is an old wisdom was reinforced for me through doing this work, and sharing in similar work of others: that social change comes from the energy of those whose lives and realities need changing. It is women who have spent the year organising for and celebrating the achievements of suffrage year, women who in my experience comprised upwards of $98 \%$ of the audiences of these events, women who participated at every level. The heavy workload undertaken by women in the events surrounding and supporting Suffrage year was of course undertaken by "choice". The kind of "choice" that is about praxis (Bawden, 1991, after Freire and others): social activism for long term real social change - for keeps. In Bawden's analysis of praxis he writes about the role of "theory for knowing, practice for doing and praxis for being": a state of knowing which is a lived state and level of knowing drawing from, and integrating, the other two levels.

There is much to learn about the lived reality of praxis from the publication Learning Liberation: Women as Facilitators of Learning (Manchester and O'Rourke, 1993). The book tells the herstories of a selection of New Zealand's leading women educationists who were asked to reflect on their experiences of "liberating learning" in a huge variety of forms, contexts and processes. Written from interviews with the 37 women, and edited by the women and the editors together, the book includes women from all sectors of education (including Marie Bell, Doreen Blumhardt, Claudia Orange, Anne Meade, Karen Sewell, Edna Tait, Deidre Tarrant). About a third are Maori women (including Keri Kaa, Patricia Grace, Hera Johns, Georgina Kirby, Hinewirangi Kohu, Irihapeti Ramsden and Iritana Tawhiwhirangi) and a small number Pacific Island women (including Poko Morgan and Loisa Crawley).

Knowing how to make a contribution to that much needed social change and when and how is where "the personal is politic" part of the sub-heading comes into the picture. For Maori women, making a difference inevitably becomes a shattering experience! In real terms it is about breaking through not only the glass ceiling, for those already inside the houses of power, looking upwards. It is also, for Maori women as a group about breaking through the glass window, for those standing outside the houses of power looking in! Breaking through the glass ceiling that traps women from moving upwards into senior management positions, and breaking the glass window that keeps Maori on the outside, has never been visualised as an easy task. But break through those glass barriers Maori and women will. Positioned differently as Maori and as women, but trapped by glass barriers none the less, barriers to our inclusion, glass barriers, in various spatial locations remind us of our positioning in this society. Positioned outside the houses of power, then trapped inside by the glass ceiling to women's promotion, Maori women live and work lives that others, Maori men and other women who are included amongst the ranks of the EEO target groups, do not. Whilst women remain so under-represented in positions of power and authority in this country, particularly Maori women, our ability to promote and create the social change needed will continue to be undermined.

Maori women were consulted extensively in the formulation of Maatua Whangai, Tu Tangata and Te Kohanga Reo programmes. They also participated on a voluntary basis in their implementation. Indeed, were it not for the unpaid effort of the women none of these programmes would have got off the ground (Department of Statistics/Ministry of Women's Affairs, 1990, p. 20).

Despite the work Maori women are doing, and which no one denies we are doing, we are still not seriously considered for representative recognition in this country. So serious has this situation become that in 1993 a group of leading Maori kuia, including the collective representation of all the presidents of the Maori Women's Welfare League, took a historic claim against the Crown to the Waitangi Tribunal about the systematic undermining of mana wahine, by the state, that has characterised this country's development. Sandra Lee's victory on election 
night, the first Maori woman ever to be elected to represent a general seat in Parliament, was a historic victory of huge significance.

In recent decades this has been further complicated by a wariness, rarely expressed openly, about promoting Maori women into leadership roles in non-Maori institutions. This is especially true of roles such as chairperson or manager where European selectors may be influenced by the false premise that because men sit on the paepae, they alone have speaking rights in Maori society (Department of Statistics/Ministry of Women's Affairs, 1990, p. 14).

The State Sector Act provides for a Senior Executive Service of senior public servants across the public service. There are currently approximately 150 public servants in this group. Of these, 20 are women: one in this group is a Maori woman (Department of Statistics/Ministry of Women's Affairs, 1990, p. 14).

The work I see Maori women undertaking in education is not a safe theoretical academic exercise or discourse, carried out at a huge distance from the world at large, indeed from life itself. It's a real, continuous process of lived engagement with the struggles of our realities on a day to day basis, and for keeps. Struggles informed by rigorous theoretical analysis and research, writing informed by the insights gained from the critical dialogue between life, work and ideas. Maori women are not in this for the short term, we are engaged in social change for the long haul, for keeps. And that is why Maori women are such a force to be reckoned with in this society.

\section{Why Maori Women "Care" and Give So Much}

Our society has not seriously sought to reflect to us as women a gender inclusive reality. The suffragists were critical in contesting that and in creating a climate in which that contestation would be a legacy. The struggles of women in this country to have the power to create our own varying realities have been mammoth.
We can never underestimate that. But they have also been positioned in relation to the Treaty, and we can never underestimate that either. To date the sisters have not always worked together, lived together and played together: our struggles as women in Aotearoa have been Treaty-based, and so have the outcomes of those struggles. The "choices" women make are hugely influenced by our differing pasts and our differing world views. Just exactly what do we share as sisters of the revolution? What stands us apart now? Making sense of the realities of Maori women's lives opens up a rich diversity of women's experience. And I'd like to visit that by reflecting on the experiences of a Maori woman educationist to illuminate the analysis I want to present.

Horiana Te Kauru Laughton (McDonald et al., 1992) was born in Nuhaka in 1899, just out of Wairoa. The fifth child in a family of nineteen, she went from Nuhaka to Turakina Maori Girls' Boarding School for a secondary education in 1915. She was born into a Maori world, with Maori language and culture as her first language; with a small rural Maori community as her turangawaewae; into a strong Mormon family and community. Aroha, whanaungatanga, te reo Maori me ona tikanga manaakitanga were central to her worldview. From a Presbyterian Church Mission School at Nuhaka she went to Turakina, across to the other side of the North Island, literally away from her whanau and hapu, to a secondary education, into a monolingual (English), monocultural (Pakeha), Presbyterian boarding environment. Not only did she make that journey, and successfully, she was dux at Turakina in 1917. She paved the way into a career for herself as a Maori woman teacher, she took up her first position in 1918, took herself through marriage and mothering towards her own independence. She was a positive role model for her family. A number of her children and grandchildren have made teaching their careers. She was successful and highly educated in both the Maori and Pakeha worlds. 
What did that Turakina schooling experience offer her and others like her? (Fry, 1985). It opened up a Pakeha world view through a very loaded set of messages: through the traditional women's role as home maker, as home keeper, as housewife. The double set of messages she got then, were from her Maori worldview and the Pakeha/English overlay her schooling experience provided. This is the "legacy" schooling offered Maori women of our grandmothers' generation. It sought to prepare them for a very clear post-school destination: in the home.

What stands out for me from this is the powerful confluence of the themes of nurturing, supporting, caring, loving.

It is not "natural" for Maori women to be like this; it is the result of very powerful socialisation processes. It helps me to understand why Maori women work as we do, in the way we do, for the struggles we believe in. About everyone and everything! Of course we care - about our language, our land, our whanau, our communities, our society, about everything! How on earth could be not care, given this scenario. Our tribal brothers may get the collectively based Maori cultural overlay centred around aroha, support and nurturing, but they don't get the women's overlay directed specifically at caring selflessly for whanau, in the home and in other private spheres of society. Our Treaty sisters may get the overlay of womanhood but their version of this is based in liberalism, with a strong individualised base to it. They do not get the cultural overlay about their roles in relation to the collective, nor as a set of values tied to the imperatives of the very survival of their descent group.

The suffrage movements showed that this was so. The women's movements that followed them in Aotearoa learnt little from this. Maori women have long struggled for Maori land, language, culture. Taking part in the wider women's movement has not meant that it has made central the struggles of Maori women, as Maori, as well as, as women. Maori women have been left with a legacy of being central to major social change, on a number of fronts, simultaneously. As I've worked and moved around women's and Maori issues in education in the last 20 years, the overwhelming impressions that I've been left with are that Maori women give beyond all reasonable claims to make "our revolutions" and other people's happen, and that other people, women included, know that this is the case and allow it to happen anyway. That's disconcerting to say the least. It is also tiring and not a Treaty-based partnership response.

That Maori language and culture have survived at all, and are in the process of revitalisation despite conflicting pressures, is a direct result of the role of Maori women, especially in the kohanga reo movement. (Department of Statistics/Ministry of Women's Affairs, 1990, p. 14).

But, critical masses (Byrne, 1988) of reflective, aware and committed Maori and women, and Maori women particularly, are emerging to share in this work - people have evolved irrevocably past the pre-women's movement days and the dependency mode of past government policies in the arena of Maori Affairs. The sisterhood has not yet, internationally, been inclusive of all groups of women. The sisterhood has not yet, to date, been Maori inclusive in Aotearoa in the way that it could and should be. There is still work to be done amongst women to enable women to talk without "talking past each other" (Metge and Kinloch, 1978). 1993 was a critical year to have this message restated and heard.

\section{The United Nations International Year of Indigenous People}

Numerous activities were planned to mark and contribute to the celebration of 1993 as the United Nations Year of Indigenous Peoples (Te Puni Kokiri, 1993, January). With the designated theme of "new partnerships" this focus resulted in considerable international as well as national activity. Conferences were held as part of these celebrations all around the world. The Third World Indigenous Peoples' Conference on Education was hosted by Australia, in Wollongong (WIPCE, 1993), and attended by a huge Maori presence from all over this country. The theme of the 
conference "Listen, Learn, Understand and Teach: the answers are within us" sent a message to those assembled from all over the world that amongst the indigenous peoples networks are to be found rich sources of ideas and understandings of the kind necessary to transform the plight of indigenous peoples on a global scale. We have much to learn from our own traditions and from those whose circumstances are similar to ours. Whilst the struggles that we as Maori, the indigenous people of our lands, face in education are international in their origin and pattern, the specific forms they have taken in Aotearoa, and our response to them, have emerged as unique in the international scene. Our story, the telling of which we are now engaging in as Maori writers with ever increasing frequency, seems to convey a significant message to others.

Conferences in New Zealand included the International Indigenous Peoples' Conference, hosted by Ngati Porou and held on the East Coast; the International Conference for Indigenous Women, hosted by the Maori Women's Welfare League, and held in Christchurch; the Maori Spiritual Elders Conference, hosted by Manu Ariki Marae, held in Taumarunui; the Cultural and Intellectual Property Rights of Indigenous Peoples Conference, hosted by Mataatua on various of their marae (Te Puni Kokiri, 1993a).

The theme of "new partnerships" has been applied to every sphere of the lives of indigenous peoples. Of particular concern at this time is the changing discourse that is appearing around the concepts of "biculturalism and bilingualism", coming from a perhaps unexpected source, economists and economic analyses. Given everything we have heard and read about from the Indigenous Peoples' Year, bilingualism and biculturalism are two of the major concerns of indigenous peoples worldwide: their language and cultural maintenance.
There are two main points to take from this discourse:

1. Biculturalism and bilingualism will be the biggest single issues we grapple with into the next century.

2. Biculturalism and bilingualism are now at the top of every agenda because of changes to the world economy.

Biculturalism and bilingualism used to be argued for in the name of natural justice, human and social rights and educational theory. Educationists know that the relationship between language and culture lies at the very heart of humanity. We become human through the learning of our culture. Our culture is expressed through the many forms our languages take. This is a given in any society, or it is not a human society. And it is education that enables this knowledge to be passed from generation to generation, maintaining links with tradition and developing, continually changing to ensure relevance in any times. Plural societies like ours, then, with more than one cultural group and language - and we are not alone in the world in this plurality - have far more complex educational tasks to face if every child is to have an equal right to language and cultural maintenance. And the complexity of this task cannot be underestimated. Indeed, the challenge of biculturalism could be said to have been on the social, political, educational and spiritual agenda since two countryfolk, by the names of Adam and Eve, claimed to be the first people on earth in the presence of, if you please, Ranginui, Papatuanuku, Tane Mahuta, Tangaroa, Tawhirimatea and the host of other atua who made the natural world live and who had already given life to Hine ahu one and her many kinsmen and women.

If every child has an equal right to language and cultural maintenance through education this is no easy task. But then, no one has ever said it was going to be easy.

But these are the kinds of arguments that we used to proffer when we faced the bicultural challenge in days of old, in prePicot, pre-restructuring days. In the course of preparing this 
paper I spoke to a friend of mind about the themes of this section. His response was immediate: wasn't that what you were doing and saying twenty years ago? He, like many other Maori teachers who graduated in the seventies, has spent the last 20 years working at the interface between Maori and Pakeha, working for bicultural development, helping people face the bicultural challenge that he lives every day as a bilingual, bicultural, highly educated and successful Maori man. He, like many of the teachers John and Hilary Mitchell (1993) interviewed in their research on why Maori teachers leave the teaching profession, left teaching frustrated by the slow progress being made. He made me think. Is the challenge the same, the work the same, the analysis the same?

As I hope this analysis will reveal, the discourse has changed in nature substantially. Over the last 20 years I have probably heard most excuses about why bilingualism and biculturalism were not real educational issues: just peripheral niceties for Maori, and Pakeha married or related through marriage to Maori, to concern themselves with. They were not about jobs, employment, the labour market, the economy: the real world. Changes to the world economy have altered all that. For a very long time. Biculturalism, bilingualism, multiculturalism and multilingualism are now about economic recovery, economic development and that is why they are on the top of the agenda for the next century, never again to be scoffed at as peripheral. That is why Ruth Richardson, then Finance Minister delivering the 1993 Budget speech, highlighted the significance of our new markets and changing industry profile.

Asian markets now account for $27 \%$ of our total exports, not far short of Australia and North America combined. In tourism there is also strong growth. Over 1,086,000 tourists visited New Zealand in the year to March 1993, an increase of over 119,000 on two years ago. The New Zealand Tourism Board estimates that on average each tourist spent 19\% more than those two years ago (Richardson, 1993, p. 9).
I want to use the ideas of two economists to explain the changes and to suggest that as educationists we need to be aware of these changes and their implications. The end does not justify the means, and in this case if we are not very careful rather than a brave new world we are in danger of recreating the old world that Maori have had to break free from a colonised, oppressed, second class reality in this our land, led by economic imperatives.

In December of 1992 I was privileged to attend a conference at Massey University called New Zealand Beyond 2000 (the Conference proceedings were published early in 1993). There I met and heard Phillip Ruthven, Founder and Executive Chairman if IBIS, one of Australia's best known business information and strategic services corporations, and Howard Fancy, Deputy Secretary of the NZ Treasury. In his superb delivery Philip Ruthven told us about the world economy, the changes it had been through in the past and the changes that it was currently undergoing. He also speculated on future developments. We were told:

We are seeing the end of a very long growth cycle or wave of almost 200 years...The two most important features of the last 200 years are: firstly, that it was dominated by the English speaking countries which went on to become what we loosely call the Western world or first economies; and second that it was an industrial revolution which began in the United Kingdom. (Ruthven, 1993, p. 4)

He continued:

The next cycle of world economic growth I think is reasonably clear. First, it will not reside in the English speaking countries of the world. It will be with the Asia-Pacific peoples of the world and perhaps one could add to that Greater Germany as it is now. Second, it will not be an industrial revolution... it will be the post-industrial age of information and services. (ibid).

He showed us lots of OHPs such as one entitled "Shares of world trade by major commodity group", which illustrated how, from 1950 to the year 2000, trading emphases would shift from 
agricultural products and manufacturing taking the greatest shares of world trade, to services accounting for nearly $50 \%$ of this trade.

Starting to get the picture ... What we need to know about why biculturalism and bilingualism are here to stay because the next cycle of world economic growth will be led by bilingual and bicultural people. In case people had not been sufficiently enlightened by this point he went on "we are part, fortunately, of the world's fastest growing economic rim - Asia Pacific". It is identified as currently producing $25 \%$ of world GDP. According to the economists it is about to pass North America and Western Europe. "By the year 2010 the Asia Pacific will be at least 35\% of world GDP and at its peak we estimate that it will reach $45 \%$ of world GDP in about 25 years ... a very, very strong growing region indeed" (Ruthven, 1993, p. 20). This places the comments that the Prime Minister made this year, that we are all Asians, into something of a perspective.

Of particular importance to us as educationists is the change from the industrial revolution to the post-industrial age of information and services. That's us, that's our work, that's where we surge forward to take our places in this new cycle of world economic growth.

Heady stuff this all was ... it was easy to relax and be washed along by the surges of economic analysis. Then, reality kicked in. Become bilingual and bicultural as a part of the economic recovery ... yes ... learn ... Maori?... For that would make you bilingual and bicultural, upskilled with a new class of personal outputs to enable you to contribute to that rapidly growing tourism industry Ruth spoke of, which helps so many people rid themselves of surplus cash ... No, not Maori. Any of the languages of the Asia Pacific rim, but not Maori. Any of the languages of the economic leaders ... that's the point. It matters not what the languages are so long as they are the languages of the economic leaders: in the last cycle of world economic growth the language was English; this time around it is the languages of Asia.
Now we were getting to the heart of the matter.

The best case scenario is that the emphasis on biculturalism and bilingualism that changes in the world economy are promoting will be added to the other analyses that have been established over the years. People will become bicultural and bilingual for an increasingly diverse variety of reasons: natural justice, human and social rights, educational theory and economic advantage. Education will have a chance to offer students access to life styles, the languages and cultures of the community, life chances and access to power and opportunity, in a bicultural and bilingual education system (Bullivant, 1981).

The worst case scenario is that this new emphasis will become the newest form of colonisation and oppression, the newest version of the assimilation policies of old. Become bilingual and bicultural, in English and the language of the market place, for economic gain ... We have heard that message before... The place of English will be assured: history and the legacy of the last economic growth cycle have seen to that. The place of Maori yet again will be relegated behind the power of other "economically viable" languages and cultures, the place English used to hold, so long, of course, as these languages are economically viable.

The case in front of us, then, is not about biculturalism and bilingualism per se. That is actually a red herring. It is about new forms of assimilation and colonisation in the name, yet again, of economic recovery and the promise of economic prosperity:

Render your sovereignty and identity unto the majority and the market place, this time round on a global, not national scale, in the name of economic gain, yet again.

What will this do for young Maori people, not getting their just rewards out of the education system we currently have? What future will they have in the promised brave new world, of bilingual and bicultural economically driven development, in a labour market serving a post-industrial age of information and 
services in which there are no places for the unskilled and semiskilled? What future indeed?

The choices in front of us could be exciting, bold and empowering. If, we make the right choices, for the right reasons. The challenge of biculturalism and bilingualism into the 1990s and beyond can only be faced by us as educationists, it seems to me, if we require that the best case scenario be adopted. That is, the emphasis on biculturalism and bilingualism that changes in the world economy are promoting should be added to the other analyses that have been established over the years. People will become bicultural and bilingual for an increasingly diverse variety of reasons including economic advantage, but not solely because of this. Education will have a chance to offer students access to life styles, the languages and cultures of the community, and life chances, access to power and opportunity, in a bicultural and bilingual education system, enabling them to take their rightful place at home as easily as abroad in this global world. To do otherwise is to offer the same choice that assimilation offered over a hundred years ago: now as then, in the name of economic prosperity.

During this year the United Nations International Year of Indigenous People, it is as well that we all ponder such possibilities with great care, for our educational policy is being increasingly influenced by economic analyses of the kind highlighted here. The document Education for the 21st Century (Ministry of Education, 1993b), integrates some such themes. The opening remarks of the document are given by the Prime Minister:

In an economy which is integrated and growing-in an inclusive economy-- there must be a place for everyone. And education is the key to participation. (Rt Hon. J. B. Bolger, Prime Minister, "State of the Nation", 10 February 1993).

That is not difficult to agree with, provided it is based on the best case scenario outlined here, not the worst.

\section{The Development Decade: 1984-1993}

Maori responses to the social and political reform of recent years have been clear. At the Hui Taumata, for example, the Maori Economic Development Summit, held when the third Labour Government came to power in 1984, Maori leaders articulated a vision for the future which was to empower Maoridom, through Maori ways, enabling Maori to attain parity with members of the wider society in all spheres of life. The objectives for Maori development, outlined at the Hui Taumata were to strive for parity between the Maori and Pakeha people of New Zealand in the areas of housing, education, land development, employment, business and health; to strengthen Maoridom's development of identity through Maori language and the heritage of the ancestors, the marae, the Maori spiritual pathway and Maori mind and tribal identity; and to achieve these objectives within the Development Decade declared by Maoridom at the Hui Taumata, from 1984-1994 (Board of Maori Affairs Report, 1986).

From the outset, the "Development Decade" involved Maoridom in a major shift in focus, what in Kuhnian terms (Kuhn, 1970) would be described as a paradigm shift, as Maori policy initiatives and directions changed to the newly proclaimed policies of Maori Development. Of particular national and international significance here was the impetus from Maori people themselves in this major change in policy. It does beg the rather obvious question: would the real policymakers in Maori Affairs please stand up? From at least 1844 to 1960 the State invested huge resources in the policy of assimilation, to be faced by a Maori community which did not die out, become completely assimilated or give up on its traditional language and cultural ways. The development of integration as the State's second phase response proved little better as a long term sustainable policy option which both the State and Maori people could accept. Maori Development, on the other hand, is a policy option offering very different possibilities, not the least of which will flow from the involvement of Maori people themselves in its development and acceptance. There are real lessons here. In matters relating to 
Maori development, at least, the "policymakers" group extends beyond those whose institutional location and job description so names them. (And I use the "at least" advisedly for it seems to me that there are many other areas, beyond Maori development, where this is the case also.) Indeed, this is exactly what Ka Awatea, A Report of the Ministerial Planning Group, advised should be the case: that the State alone could not, nor should it, be solely responsible for Maori development. That smacks of the dependency mode which characterises colonisation and which Maori development seeks to break. The introduction to Part Four of the report, "Strategies for change" reads:

In this part of the report we recommend a number of key strategies which we believe should be initiated and funded from Vote: Maori Affairs. In recommending these key strategies we emphasise the view that Government cannot and should not be involved in all areas of Maori development. Some areas of Maori development should be contributed to by the private sector while others areas remain the responsibility of Maori to help themselves (Henare et al., 1991, p. 47).

Brian Bullivant's classic study The Pluralist Dilemma in Education (1981), a major comparative study of cultural pluralism in Canada, the USA, Britain, Fiji, Australia and Hawaii, identifies many similarities in the patterns of impact and response colonisation has had at an international level. In Aotearoa this international pattern has been replicated at the generic level of state policy (Irwin, 1989). The specific form that colonisation and the implementation of policies based on it took, however, was unique to New Zealand in significant ways. The variation is worth close consideration. Claudia Orange has noted

In many respects New Zealand, in spite of the treaty, has been merely a variation in the pattern of colonial domination of indigenous races $(1987$, p. 5).

It is, I believe, vital to understand more of what this "variation" entailed if we are to understand the fullness of our story and its significance in the global scene. One of the sites of struggle for
Maori which has shaped the colonisation of Maori in a unique fashion, is the Treaty of Waitangi. Although this has been a major site of contestation and bitter struggle between iwi Maori and the State from the time of its signing to the present, Britain did sign a formal treaty with the tribes of Maoridom, the Treaty of Waitangi, on 6th February, 1840. Whilst Maori are a tribal people, and there are many tribes throughout the land which could have resulted in numerous treaties being signed at the tribal level, only one Treaty was signed between the State and iwi Maori. Since the time of its signing, the Treaty has provided Maori with a legal, political and moral framework from which to challenge the state. Whilst our history is replete with examples of Maori leaders actually trying to secure from the State the control and resources the Treaty promised, it is only in recent decades that the state has taken the Treaty into serious consideration. The effect of the state ignoring just Maori grievances for over 150 years has been a critical factor in recent developments in Aotearoa. It has motivated iwi Maori to move from a welfare and dependency mode, in which the State control is central, and which has been a global characteristic of colonisation, into a much more entrepreneurial mode of Maori development with self determination at its core.

In a keynote address to the International Indigenous Women's Conference, held in Aotearoa in February 1993, Dalee Sambo spoke about the development of a draft Universal Declaration on Indigenous Rights, part of the work of the United Nations Economic and Social Council Working Group on Indigenous Peoples. She outlined a number of specific international standards that have emerged from this work: the "recognition of collective rights; the recognition of indigenous peoples' right of self determination; the essential principle of consent; the right of indigenous peoples to determine their own priorities; the protection of the "integrity" of indigenous values, practices, institutions and environment; and sustainable and equitable development" (1993, pp.3-6). Speaking about indigenous peoples all over the world, Dalee observed: 
to this day there continues to be an unwavering determination toidentify both self and community as indigenous, despite rapid social, environmental and economic change. The legacy of outside control is what indigenous peoples today are fighting against (1993, p. 1).

The integration of these international standards is central to the process of change that Maoridom is engaged in in Aotearoa. Maoridom has increasingly refocused policy direction from the bicultural development policy framework into one called Maori development, emphasising tino rangtiratanga, self determination.

The shift has been a critical one, indeed what is rightly termed a major paradigm shift. Writing about "The Great Paradigm Shift" in the international best seller Revolution from Within, Gloria Steinem wrote that:

The biggest and most far reaching kind of cognitive therapy is a paradigm shift: a change in the organising principle that underlies the way we think about ourselves and the world (1993, p. 217).

The Hui Taumata sent out clear signals that Maoridom was on the move, taking the initiative to articulate in the vision of Maori Development a new time of Maori activity, initiative and innovation; an initiative designed to end paternalistic policies which had required Maoridom to be dependent on the state whilst at the same time being berated by the state for this dependency (the very relationship that the state spent over 150 years nurturing!) This is the kind of change that Maoridom is engaged in now at whanau, hapu, iwi, national and international levels (Irwin, 1993). The effectiveness of this shift has led to the development of a diverse range of initiatives of Maori development in education (Irwin, 1992) some of which are now recognised as major movements, not just successful initiatives of a small scale nature, in radical educational change (Smith, G., 1992a, b; Smith, L., 1992a, b).

\section{Conclusion}

\section{Tungia te ururua}

Kia tupu whakaritorito

te tapu o te harakeke.

Clear away the undergrowth

so that new shoots (ideas)

may emerge.

(Henare et al., 1991, p. 47)

Though the wider society beyond Maori society in Aotearoa has historically had great difficulty recognising the Maori world, never mind affirming its worth or validating it as real, Maori are taking control of the task of turning this situation around, and moving beyond colonisation into new post-colonial formations and realities. Changes in policy direction to policies of Maori development have created a climate in which the possibilities for real change in this sphere are increasingly shared by Maori and the State. The many and varied events of 1993 have provided a context from which to reflect on both the need for this change of policy and something of its impact: women's issues, the global perspective of the UN Indigenous Peoples' Year and election year have all contributed to the framing of the analysis. A major tension which continues to plague Maori education into the 1990s is the assumption that Maori education is an inwardly focused enterprise, concerned only with educating Maori children to live in their immediate Maori community, with a backward looking yearning for the days of old, a local not a global concern. Maori education is vitally concerned with "thinking globally, acting locally" (Irwin, 1994).

\section{References}

Bawden, Richard "Praxis: the essence of systems for being", in HERDSA Papers, Vol. 14, (ed) Viskovic. Wellington: HERDSA, 1991. Board of Maori Affairs, Report, Wellington, 1986. 
Broughton, R. Nga Mahi Whakaari a Titokowaru, Wellington: Victoria University Press, 1993.

Bullivant, B. The Pluralist Dilemma in Education, Sydney: George Allen and Unwin, 1981.

Butterworth, Karen Women's Voices: Six Lunch Hour Talks Celebrating Suffrage Year in Otaki, Otaki: Otaki Suffrage Coalition, 1993.

Byrne, Eileen "Educational Policy: Institutional Ecology and Management Directions", Paper presented at the International Forum on Women in Public Sector Administration. July, Queensland Institute of Technology, Brisbane, 1988.

Coddington, Deborah Turning Pain into Gain: The Plain Person's Guide to the Transformation of New Zealand 1984-1993, Auckland: Alister Taylor, 1993.

Coney, S. Standing in the Sunshine, Auckland: Penguin Books Ltd, 1993.

Davies, L. and Nicholl, K. Te Maori i roto i nga Mahi Whakaakoranga Maori in Education, Wellington: Learning Media, 1993.

Department of Statistics/Ministry of Women's Affairs Women in New Zealand, Wellington: Department of Statistics/Ministry of Women's Affairs, 1990.

Else, A. et al. Women Together: A History of Women's Organisations in New Zealand, Wellington: Historical Branch of Internal Affairs/Daphne Brassell Associates, 1993.

Henare, D.; Comer, L. and Thompson, M. Ka Awatea, Wellington: Ministry of Maori Development, 1991.

Irwin, K. G. "Maori Education in 1991: A Review and Discussion", in Manson, H. (ed) New Zealand Annual Review of Education, 1:1991, Wellington: Department of Education, Victoria University of Wellington, 1992, pp. 77-112.

Irwin, K. G. "Maori Education in 1992: A Review and Discussion" in Manson, H. (ed) New Zealand Annual Review of Education, 2:1992, Wellington: Faculty of Education, Victoria University of Wellington, 1993, pp. 71-91.

Irwin, K. G. "Multicultural Education: The New Zealand Response", NZJES Vol. 24, No. 1, pp. 3-17, 1989.

Johnson, Patricia and Pihama, Leonie "What counts as difference and what differences count?: Gender, Race and the Politics of Difference", Paper presented at NZARE, Hamilton, December, 1993.
Kuhn, Thomas S. The Structure of Scientific Revolutions, Chicago: University of Chicago Press, 2nd Edition, 1970.

MacDonald, Tui Te Ara Tika: Maori and Libraries - A Research Report, 1993.

Manchester, J. and O'Rourke, A. Learning Liberation: Women as Facilitators of Learning, Wellington: Women's Suffrage, 1993.

Metge, Joan and Kinloch, P. Talking Past Each Other: Problems of Cross Cultural Communication, Wellington: Victoria University Press, 1978.

Middleton, S. Educating Feminists: Life Histories and Pedagogy, New York: Teachers College Press, 1993.

Ministry of Education Nga Tikanga Tekau o Te Tatai Mo Te Akoranga Maori: Ten Point Plan, Wellington: Learning Media, 1993e.

Ministry of Education Three Years On: The New Zealand Education Reforms 1989-1992, Wellington: Learning Media, 1993a.

Ministry of Education Education for the 21st Century, Wellington: Learning Media, 1993b.

Ministry of Education Education Statistics of New Zealand, Wellington: Ministry of Education, 1990

Ministry of Education New Zealand Curriculum Framework, Wellington: Learning Media, 1993c

Ministry of Education Te Whariki: Draft Guidelines for Developmentally Appropriate Programmes in the Early Childhood Services, Wellington: Learning Media, 1993d.

Mitchell, John and Hilary Why Maori Teachers Leave the Teaching Profession, Wellington: NZCER, 1993.

New Zealand Beyond 2000. Future shape of the university environmental analysis workshop, Palmerston North: Massey University, 1993.

Orange, Claudia The Treaty of Waitangi, Wellington: Allen and Unwin/ The Port Nicholson Press, 1987.

Rei, Tania Maori Women and the Vote, Wellington: Huia Publishers, 1993.

Richardson, Ruth Budget Speech 1993, Wellington: Government Printer, 1993.

Ruthven, P. "The Future of Australasia”, in New Zealand Beyond 2000. Future shape of the university environmental analysis workshop, Palmerston North: Massey University, 1993.

Sambo, Dalee Address to the International Conference for Indigenous Women, Christchurch, New Zealand, Unpublished paper, February, 1993. 
Smith, Graham "Kura Kaupapa Maori: Contesting and Reclaiming Education in Aotearoa", in Douglas, R. and Poonwassie, D. H. Education and Cultural Differences: New Perspectives, London: Garland Publishing, 1992.

Smith, Graham Hingangaroa “Tane-nui-a-Rangi's Legacy ... Propping Up the Sky", Unpublished paper presented at the NZARE/AARE Annual Conference, Geelong, Australia, 1992a.

Smith, Linda "Kura Kaupapa Maori and the Implications for Curriculum", in McCulloch, Gary (ed) The School Curriculum in New Zealand: History, Theory, Policy and Practice, Palmerston North: The Dunmore Press, 1992b.

Smith, Linda Tuhiwai "The dilemma of a Maori Academic" Unpublished paper presented at the NZARE/AARE Annual Conference, Geelong, Australia, 1992a.

Steinem, Gloria Revolution from Within, London: Corgi Books, 1993.

Sturrock, Fiona The Status of Girls and Women in New Zealand Education and Training, Wellington: Learning Media, 1993.

Szekely, Chris Te Hikoi Marama: A Directory of Maori Resources, Wellington: Bridget Williams Books, 1993.

Te Puni Kokiri Newsletter Issue No. 8, January, Wellington: Te Puni Kokiri, 1993a.

Te Puni Kokiri Newsletter Issue No. 14, July, Wellington: Te Puni Kokiri, $1993 b$.

\section{The author}

Kathie Irwin is a Senior Lecturer in Education at Victoria University of Wellington. She teaches courses in Maori Education and contributes sections in others on Multicultural Education, Maori Women and Education, Research and the Maori Community and Maori Women's Studies. In 1991 she co-edited Feminist Voices (Oxford University Press) and contributed a paper to it, "Towards Theories of Maori Feminism". She contributed "Becoming an academic: contradictions and dilemmas of a Maori feminist" to Women and Education in Aotearoa Volume II (Bridget Williams Books Ltd). 